\title{
Are Bronchioles Fueling Burning Alveoli in Lung Fibrosis?
}

\section{Bruno Crestani}

APHP, Hôpital Bichat, Service de pneumologie, Centre de compétence des maladies pulmonaires rares, and INSERM, Unité 700, Faculté de Médecine Paris 7 Denis Diderot, Paris, France

Sometimes humans refuse to look at the world as it is and prefer to see the world as it should be, but hopefully, sometimes someone turns up and leads us back to the right path. I suspect that it is exactly the role of George Castro Figueira de Mello and his colleagues in this issue of Respiration, taking us by the hand to bring us back to basics [1]. What they remind us of is obvious: alveoli are linked to bronchioles. This is so evident that most of us just forgot it when thinking of lung fibrosis. In the most popular dogma, lung fibrosis is regarded as impaired communication between alveolar epithelial cells and fibroblasts [2]. Although this pathophysiological model renewed our thinking about the disease, it did not consider several important components of the respiratory system such as blood vessels, the pleura and, indeed, the bronchial tree.

Fortunately, this is a time for rediscovery. Alterations in the pulmonary circulation in lung fibrosis are being illuminated and this may translate into therapeutic advances for patients [3]. At the same time, pleural mesothelial cells were ascribed a role in the pathophysiology of pulmonary fibrosis, particularly via mesothelial-mesenchymal transition [4]. This is particularly important for idiopathic pulmonary fibrosis (IPF), a disease that begins and predominates in the subpleural regions of the lung. In their study, our Brazilian colleagues remind us that lobules encompass bronchioles, and that small airways are involved in the fibrotic disease.

\section{KARGER}

Fax +4161306 1234 E-Mail karger@karger.ch www.karger.com (c) 2009 S. Karger AG, Basel 0025-7931/10/0794-0277\$26.00/0

Accessible online at: www.karger.com/res
Although narrowing and stenosis of the small airways were noted in the original description of IPF by Hamman and Rich [5], subsequent morphologic studies have largely concentrated on the alveoli and alveolar interstitium, perhaps because the significance of small airway abnormalities in the pathophysiology of chronic fibrotic pulmonary disorders was hardly recognized. In a seminal work comparing physiologic and morphologic observations in 18 patients with what was called IPF at that time, Fulmer et al. [6] clearly demonstrated morphologic and physiologic changes in the small airways of patients with mid-course fibrotic lung disease - in both smokers and non-smokers. Morphologically, they described a pattern of peribronchiolar fibrosis and inflammation without significant bronchiolitis, leading to their conclusion that fibrosis of the small airways is secondary to the interstitial process. Physiologically, commonly employed methods for assessing small airway disease, e.g. the single breath nitrogen test and closing volume determination, proved not useful in patients with fibrotic disease probably because of the increase in the elastic recoil associated with the disease. By contrast, abnormalities in dynamic lung compliance and alterations in maximal expiratory flow volume curves were strongly associated with airway narrowing in those patients. Interestingly, the overall estimate of airway narrowing neither correlated with total lung capacity nor with vital capacity, functional residual capacity or carbon monoxide transfer. Altogether, these

Prof. Bruno Crestani

Service de pneumologie A, Hôpital Bichat

16 rue Henri Huchard

FR-75877 Paris cedex 18 (France)

Tel. +33 1402568 00, Fax +331402588 18, E-Mail bruno.crestani@bch.aphp.fr 
observations and those of European researchers [7] drew increased attention to airway dysfunction as a cause for increased work of breathing and ventilation-perfusion mismatching leading to hypoxemia in fibrotic lung disease.

The work by George Castro Figueira de Mello is a step ahead as it shows that morphological abnormalities of airways are seen both in IPF, as currently defined, and in nonspecific interstitial pneumonia. Most importantly, and in apparent discrepancy with their illustrious predecessors, these authors also suggest that small airways could be actively involved in the fibrotic process during idiopathic fibrotic lung disorders, as they demonstrate that bronchiolar epithelial cells overexpressed matrix metalloproteinase (MMP)-7 and MMP-9 compared with controls. MMP overexpression was established only with immunohistochemistry without direct evidence of increased local activity of these proteases, strongly favoring of the hypothesis that bronchiolar epithelial cells could contribute to local remodeling of the peribronchial interstitial lung tissue.

Bronchiolar epithelial cells, instead of type 2 pneumocytes, are then the main source of epithelial renewal in the fibrotic lung, particularly in areas with very severe lung damage [8]. Whether these cells originate from bronchioalveolar stem cells [9] or migrate from the bronchioles down to the alveolar spaces in the course of lung injury and repair processes remains to be determined. These cells are not only unsuitable for gas exchange, they are also likely to contribute to the ongoing fibrogenic process through their capacity to undergo an epithelial-mesenchymal transition, as observed in mice [10], and through their secretion of profibrotic mediators such as chemokines and growth factors $[11,12]$. Since bronchiolar cells have been shown to respond to an insult with chronic activation of profibrotic genes, contrary to lung parenchyma [13], their presence in the distal lung might contribute to the chronicity of the fibrotic process. Finally, as lung cancer kills $10 \%$ or more of IPF patients [14], a better knowledge of the process leading to the chronic proliferation of bronchiolar epithelial cells in the fibrotic lung could translate into prevention of this deadly event.

In conclusion, due to the undetermined role of bronchioles in fibrotic lung disease, having a look at the bronchioles could bring fresh air to the alveoli.

\section{References}

1 Figueira de Mello GC, Ribeiro Carvalho CR, Adib Kairalla R, Nascimento Saldiva $\mathrm{PH}$, Fernezlian S, Ferraz Silva LF, Dolhnikoff M, Mauad T: Small airway remodeling in idiopathic interstitial pneumonias: a pathological study. Respiration 2010;79:322332.

2 Selman M, Pardo A: Idiopathic pulmonary fibrosis: an epithelial/fibroblastic cross-talk disorder. Respir Res 2002;3:3.

3 Renzoni EA, Walsh DA, Salmon M, Wells AU, Sestini P, Nicholson AG, Veeraraghavan S, Bishop AE, Romanska HM, Pantelidis P, Black CM, Du Bois RM: Interstitial vascularity in fibrosing alveolitis. Am J Respir Crit Care Med 2003;167:438-443.

4 Decologne N, Kolb M, Margetts PJ, Menetrier F, Artur Y, Garrido C, Gauldie J, Camus P, Bonniaud P: TGF- $\beta 1$ induces progressive pleural scarring and subpleural fibrosis. J Immunol 2007;179:6043-6051.

5 Hamman L, Rich AR: Acute diffuse interstitial fibrosis of the lungs. Bull Johns Hopkins Hosp 1944;74:177-212.
6 Fulmer JD, Roberts WC, von Gal ER, Grystal RG: Small airways in idiopathic pulmonary fibrosis. Comparison of morphologic and physiologic observations. J Clin Invest 1977; 60:595-610.

7 Yernault JC, de Jonghe M, de Coster A, Englert M: Pulmonary mechanics in diffuse fibrosing alveolitis. Bull Physiopathol Respir (Nancy) 1975;11:231-244.

8 Kawanami O, Ferrans VJ, Crystal RG: Structure of alveolar epithelial cells in patients with fibrotic lung disorders. Lab Invest 1982; 46:39-53.

9 Kim CF: Paving the road for lung stem cell biology: bronchioalveolar stem cells and other putative distal lung stem cells. Am J Physiol Lung Cell Mol Physiol 2007;293: L1092-L1098.

10 Wu Z, Yang L, Cai L, Zhang M, Cheng X, Yang X, Xu J: Detection of epithelial to mesenchymal transition in airways of a bleomycin induced pulmonary fibrosis model derived fromanalpha-smooth muscle actin-Cre transgenic mouse. Respir Res 2007;8:1.
11 Betsuyaku T, Fuke S, Nasuhara Y, Morikawa T, Kondo S, Nishimura M: Diverse expression of antioxidants and inflammatory chemokines in terminal bronchiolar epithelium in chronic obstructive pulmonary disease. Proc Am Thorac Soc 2006;3:471-472.

12 Corrin B, Butcher D, McAnulty BJ, Dubois RM, Black CM, Laurent GJ, Harrison NK: Immunohistochemical localization of transforming growth factor-beta 1 in the lungs of patients with systemic sclerosis, cryptogenic fibrosing alveolitis and other lung disorders. Histopathology 1994;24:145-150.

13 Churg A, Zhou S, Preobrazhenska O, Tai H, Wang R, Wright JL: Expression of profibrotic mediators in small airways versus parenchyma after cigarette smoke exposure. Am J Respir Cell Mol Biol 2009;40:268-276.

14 Yuichi O, Takafumi S, Tateaki N, Noriyuki E, Dai H, Tomoyuki F, Yutaro N, Naoki I, Hirotoshi N, Kingo C: Cumulative incidence of and predictive factors for lung cancer in IPF. Respirology 2009;14:723-728. 